\title{
Religiosity Online:
}

\section{Holy Connections with the Homeland by Filipino Migrants in Japan}

\author{
Reggy Capacio Figer (Corresponding author) \\ Doctoral Program in International and Advanced Japanese Studies \\ Graduate School of Humanities and Social Sciences, University of Tsukuba \\ 1-1-1 Tennoudai Tsukuba, Ibaraki, 305-8571, Japan \\ E-mail: reggyturf@yahoo.com
}

Winton Lou G. Ynion

Asia Research Insititute, National University of Singapore

NUS Bukit Timah Campus, 469A Tower Block, \#10-01

Bukit Timah Road, 259770, Singapore

E-mail: theaquarianfellow@yahoo.com

\begin{abstract}
Religion is an indelible aspect of Filipino culture. It has been challenged by different modes of discourses and has resulted to a variety of sects (kapatiran) and cults (samahan). In the contemporary dispersion of human capital, Filipinos have been caught in the suspension of the performance of religiosity. It is on this context that Internet has been utilized to develop significant network connections among Filipinos in diaspora. This paper seeks to examine the interface between religiosity and the Internet use of Filipino migrants in Japan. Drawing from the textual analysis of online postings on Timog.com, it is evident that Filipino religiosity is reproduced as a form of long-distance ritual practice and cyber pilgrimage. Through the interchange of affective subscription to one's religion, Filipinos develop connections among online migrants and with the sacred homeland.
\end{abstract}

Keywords: Filipino migrants, Internet, Homeland, Religiosity online

\section{Introduction}

Among the three G's that Spanish colonialism downloaded at the portal of Philippine islands, it was the God, the other two being the Gold and the Glory, that brought tremendous permutations to the future of Filipino society. The rapid Christianization by the friars during the $16^{\text {th }}$ century proved ineffaceable throughout the centuries of nation-formation. At the onset of conversion project, the Dominicans published Doctrina Christiana in 1593, which contained Christian mantras and narratives of saints, while other religious orders were traveling to the islands that were non-resistant to foreign domination or were non-isolated from the center of colonial power. The book, along with the Bible, is the first text that defined religion as a reproducible abstract.

The Catholic Church played two important roles along the course of Philippine history. It had called on devotees to indigenize the aspects of Christianity that were dramatically incoherent to folk traditions. Result of such was the foundation of two other dominant Christian kapatirans (sects) - the Iglesia Filipina Independiente (Philippine Independent Church) and the Iglesia ni Kristo (Church of Christ). The sects were results of philosophical examinations of the doctrines of Catholicism and, in more instances, of symbolical accommodations for the Philippine context. Consequently, kapatiran roots from patid which means "divide." In Eucharistic celebrations, mass attendees are addressed as kapatid ("sister and brother") to suggest God's non-gendered and non-transgressive eschatology. During national elections, those who seek public office court the sects for divine endorsement. While there is an official partition between the Church and the State, the former had once showed its influence and power in the construction of a nation. The EDSA Revolution in 1986 (also referred to as People Power), which overthrew the 20-year dictatorship of 
Ferdinand Marcos, proved that Filipinos have the ability to re-form and re-signify Catholicism according to their national needs (Ellwood Clayton, 2003).

\section{The Advent of Technology and Its Appropriation in Religious Practices}

With the Spanish and American colonization being the first two consecutive formations that Filipinos experienced, Pertierra and Ugarte (1994) argued that the third formation is the cell phone revolution. Paule (2000) analyzed the phenomenal growth of cellular mobile phones in the Philippines, in particular, the ways in which Filipinos have appropriated technology. In her study, the cellular phone was most importantly an instrument of a wireless revolution which resulted to EDSA Revolution II. The Filipinos had found the interactivity and mobility of this technology and had used this in calls for protest actions and political agenda - all for nationalism. But there is another love that is a significant domain in the texting phenomena in the country - the sacred love: the relationship between SMS (short messaging service) and God. Ellwood-Clayton (2003) argued that local practice of religiosity is facilitated and performed through folk text Catholicism, and is illustrated through users' communiqué (barkada gospel) and through commercial avenues catering to the pious (evangelical gospel) (p.254). She added that "regular religious supplemented text communication creates an independent form of community religiosity that is more or less autonomous from the Catholic Church" (p.255). The sending of God's words through text messages subverts the standard means of church, Bible and priest, and

... fosters virtual communities that cut across temporal and geographic constraints and works to maintain relationships and support community-based forms of religiosity. Aided by cyberspace, religious communication, as a micro, daily social relation occurring between individuals, has an alternative site of expression; it has literally become based in the hands of the people rather than primarily through institutions (pp. 258-259, emphasis supplied).

Ellwood-Clayton noted the commercialism of religiosity in the Philippines and the acknowledgment of the Catholic Church of the SMS phenomenon. In 2002, the Church launched "Catextism," a service that provides spiritual readings and prayers through SMS transfer in cyberspace (http://www.cbcponline.org/news/Archives/may2002/news6-may5.html). To subscribe, a texter keys in the word "Amen" on his/her phone and sends it to a particular number, and subsequently receives a menu of spiritual readings and prayers. The use of cellular phone as a medium in sending and receiving spiritual messages confirms the built-in tendency of Filipinos to find interstices between their faith and technology. This meeting of religion and communication medium, too, substantiates the unstoppable convergence of premodern and postmodern cultures to initiate a compromising and livable world mired by politico-religious divisions, diaspora and migration, and transnationalism.

\section{Diaspora and Religiosity Online}

Among those who are caught between wars and divisions, especially in the post 9-11 era, are the transnationals - the immigrants and the overseas contract workers. These people on the global frontier look for connections with their place of origin rather than with their host community. Tordillo (2007) remarked that such "uprootedness leads migrants to seek channels of connection, socialization and ties" (p.5). Palumbo-Liu (1999) emphasized that "[D]iaspora does not consist in the fact of leaving Home, but in having that factuality available to representation as such" (p.35). A key characteristic of diaspora is the relationship between globally dispersed yet collectively self-identified ethnic groups and their countries of origin and settlement (Vertovec, 1999). Apparently, it is the cyberspace that provides myriad opportunities for streaming interactivity with the homeland. As electronic citizens, the transnationals brought concrete and abstract things that they need in establishing connections with their new communities, including their religion.

When religion was becoming a significant component of cyberspace, a number of research projects were conducted to assess the occurrence of religion on the Internet. Interesting results came from the Time Warner Company research which, in 1996, estimated that there were three times as many sites concerning God and spirituality than there were concerning sex (see Helland, 2007). One of the recent studies, conducted by the Pew Internet and American Life Project, found that " $64 \%$ of wired Americans have used the Internet for spiritual or religious purposes" (Hoover, Clark, \& Raine, 2004). These demonstrate, Helland (2007) observed, that religion on the Internet is a common aspect of the new communication medium which "has been embraced by most of the world's religious traditions, to the point that not having Internet representation is a rarity for a religious organization" (p.2). Members of a religious tradition viewed the Internet as a "spiritual medium facilitating religious experience, a sacramental space suitable for religious use, a tool promoting religion or religious practice and a technology for affirming religious life" (Campbell, 2005, pp. 9-10). Consequently, Dawson and Cohan (2004) enumerated the reasons for the urgency of research on online faith:

1. We need more and better studies of who is using the Internet for religious purposes, how they are using it, and why. In this regard we need longitudinal 
studies to detect any changes that are happening with the passage of time and increased experience online.

2. We need studies of the nature and quality of people's experiences doing religious things online. In this regard we need surveys and interviews of users and case studies of groups, Web sites, or particular activities.

3. We need studies of the relationships between people's religious activities online and offline, as well as their religious activities online and offline and other kinds of activities online and offline. We need to gain a better grasp of the overall social context of cyber-religiosity.

4. We need detailed and comparative studies of the specific religious activities online. How is the Internet being used to engage in such things as prayer, meditation, ritual, education, and organizational tasks, and to what effect?

5. We need studies of how the features of the technology itself are being utilized in the service of religious ends and with what consequences for the intrinsic and the social aspects of religious life? What are the actual and potential implications of hypertextuality for religion, for example? Are there special interface issues affecting the religious uses of this technology? How can the technology be changed or improved to facilitate its religious utilization?

6. We need to discern whether the technological and cultural aspects of the Internet are better suited to the advancement of one style or type of religion over another. Is the preponderance of Neopagan activities online, for example, coincidental? Or is the Internet better suited, for instance, to the practices and organizational structure of Hinduism than Catholicism? What is the case, why, and with what implications for the future? (pp. 10-11)

The foci and context in this study are the Filipino cyber migrants and immigrants in Japan. The Philippines is the only predominantly Christian nation in Asia (Cannell, 1999; Cacho, 2007; Tigno 2007), and is among the leading countries that deploy their citizens for overseas work. The two facts bring interest in the study of spirituality of Filipinos vis-à-vis their cyber religious acts. Tigno (2007), writing on the serialized Filipino identity in Japan, argued that "religious practice and religiosity are deeply rooted in the Filipino national psyche" (p. 3). The celebration of the Eucharist, he cited, provides a "social outlet and support network to Filipinos who are lonely and depressed overseas and reproduces their Filipinoness in the process" (p.4).

This study banks on the non-participatory netnography on the religion and spirituality threads of Timog.com, the most preferred online community of Filipinos in Japan as based on the number of members the forum possesses. The researchers were merely observers on the dynamics of religious discourses and debates that unfolded and transpired in the forum. The six-month observation of the updates and exchanges of threads and replies provided a close connection between diaspora and spirituality and underlines the Internet as an effective medium in finding a food for the soul, so to speak.

\section{Cyberspace as the Site of Online Religion}

Brasher (2001), looking at cyberspace as "a fiction of public etiquette that orients people in a virtual environment," (p.5) revealed that one of the best-kept secrets of cyberspace is the surprising amount of religious practice that takes place within its virtuality. These activities, she adds, "encompass every major religious tradition in the world, most new religious groups, and innumerable social movements that function as de facto religions..." (p.6). Helland (2007) cited several benefits of the Web to religious communities living in diaspora:

First, it allowed them to present information about their religious beliefs, practices, and ethics to the communities in which they were located and also to the world at large... (Second), the web was an inexpensive and effective way to communicate religious information... (Third), that it easily allowed people to come together from across the globe to network based on their diaspora religious tradition (p.10).

Even the Vatican has seen the indelible impact of cyber space and is deemed to have seen the opportunities and privileges of making Christianity online. The Vatican website (http://www.vatican.va/), designed in 1995 by a group of Benedictine Monks, has millions of internal web pages hosted on three super computers named after the three archangels: Raphael, Michael and Gabriel. The site is available in "six languages and contains a massive archive and information on doctrine and beliefs, the church's history, and Catholicism" (Helland, 2007, p.8). There are, however, no interactive areas and external links (see Helland, 2002) and transaction tools to communicate with the moderator or with 
the Carmelengo, or, say, with the Pope. The Vatican and many other official religious websites began to use the Web for "one-to-many" communication - messages are relayed but web site does not allow interaction - what Helland (2004) calls as "religion online" in contrast with "online religion" which invites Internet visitors to participate in religious practices.

While the Vatican website remains "closed," it concedes with the Internet's capacity to "spread" the word of Christ and to "multiply" believers. In May 12, 2002, Pope John Paul II issued the following message on the World Communication Day:

\begin{abstract}
The Internet causes billions of images to appear on millions of computer monitors around the planet. From this galaxy of sight and sound will the face of Christ emerge and the voice of Christ be heard? For it is only when his face is seen and his voice heard that the world will know the glad tidings of our redemption. This is the purpose of evangelization. And this is what will make the Internet a genuinely human space, for if there is no room for Christ, there is no room for man. Therefore, on this World Communications Day, I dare to summon the whole Church bravely to cross this new threshold, to put out into the deep of the Net, so that now as in the past the great engagement of the Gospel and culture may show to the world "the glory of God on the face of Christ" (2 Cor 4:6). May the Lord bless all those who work for this aim. (http://catholiceducation.org/articles/media/me0024.html)
\end{abstract}

In maximizing the potential of the Internet, many-to-many, non-hierarchical communication and interaction among participants appeared, such as that of Timog.com. In this case, individuals "interacted with the religious belief systems presented... contributed their personal beliefs and received personal feedback... [T] hey were not simply passive recipients of information; rather they become actively involved in a dialectic process" (Helland, 2007, pp.7-9). Hoover, et. al. (2004) called each recipient as the "online faithful" (p.20). They devote and use the Internet for personal spiritual matters more than for traditional religious functions or work related to their place of worship. But their religious and faith activities online appear to supplement their already fervent devotion and dedication to their congregations.

\title{
5. Timog.com and the Filipino Migrants in Japan
}

Timog.com site, established in 2004, was not unique, in that many ethnic groups also developed websites providing information about their lives and their practices along with discussion areas where their people in diaspora could go online to share with co-members of their culture. The site catered specifically to Filipinos in diaspora in Japan by providing information about the culture and mores of Japanese people, the news and updates of about the homeland, and the issues that Filipinos face in Japan. Membership in Timog Forum is open, quick and anonymous: "open" because everyone can join, "quick" because one can register and post in the forums in less than 5 minutes, and "anonymous" because the site does not require stringent personal details from members. The moderator said that the objective of the site is to provide a space for Filipinos in Japan - especially on aspects that define their alienation. Information guides (travel, technology, legality, jobs, and translation) have individual links and discussion boards. Along with providing this information, the website hosted a vibrant discussion area where people could exchange ideas about their religious beliefs and practices. The best posts in Timog Forum, the moderator emphasized, are those that are "informative, original, and are related to Filipinos in Japan."

The Timog.org forum is divided into seven links: (1) General, (2) Community, (3) Living, (4) Recreation, (5) Off-topic, (6) Students, and (7) Market. In these seven links, religious posts are found in the "Religion \& Inspiration" section of the Off-topic group. Table 1 summarizes the activities in the group and the frequency percentage of each against the total number of replies. The posts are grouped according to activity thread type. The figures only involved the first half of 2009 or from January 1 - June 30, 2009.

In Timog.com, discussions ranged across a number of topics which generate calm debates over religious beliefs, truth claims and Biblical subscription. There were no moderators to limit or censor discussions, though there are some "rules" to follow in posting. Participants are reminded from posting "rude, inflammatory or insulting" messages, as well as "hoaxes, chain letters, fake virus warnings and trite inspirational messages" (Timog.com, 2009). The participants are also expected to exhibit politeness and acceptance especially on topics that arouse different opinions like "politics, religion, and ethics" (Timog.com, 2009)

Among the types of threads, the Bible-related discussion (35.25\%) and Christianity debate $(29.74 \%)$ that took most of the attention of members-posters. It is necessary to note that members of the forum were not coming from the same religious sect, thus differences in interpretation and signification of the sacred text, the Bible, have been the favorite topic of discussion and debate.

It may be inferred that the most active thread along the stages of forum is the "Prayer request." In this thread, participants post their prayers ranging from generic and abstract written recitation of prayers to specific and concrete 
requests. While there were only 200 replies as of the end of June 2009, the thread earns the most number of views $(8$, 201). Prayer requests range from asking for safety of loved ones back home and thanksgiving for graces and blessings.

Based on the time delimitation of the study, the section has 651 threads and 13, 894 posts. Table 2 summarizes the threads and their corresponding total of replies and posts. Only threads that were posted from January 1, 2009, achieved a (hot thread) mark, and received 100 replies are considered for this study.

\section{Dynamics of Religious Discourse Online: An Example}

Because of the fact that these Filipinos are away from home, their natural compassion for fellow Filipinos abroad is undeniably immense. They do not have anybody to lean onto except for their kababayan (co-Filipino). Hence, prayer requests abound in Timog.com. Filipinos asked help for prayers from fellow online members to implore for him/her strength and protection from harm and sickness while in Japan. Another member called upon his kababayan to pray for him amidst his legal battle for visa acquisition. These examples provide the notion that indeed the Internet has become a pivotal venue for Filipino migrants to activate their religious and faith activities online. Unlike before when websites are only means to supply and disseminate information, now, websites become interactive platforms for religious pursuits. Cases in point also illustrate Filipino migrants' identity in Japan as compassionate people to their kababayan and this compassion is very much translated in their religious practices and religiosity online.

Another good example of the dynamics of argumentation that occurred in the forum can be seen in the "Images of saints: Forbidden" thread. LIVING IMAGE who was in Manila, as his user info locates, started the thread on April 2, 2009 asking whether images of saints are forbidden or whether there is an existing misinterpretation that God prohibits the creation of the images. LIVING IMAGE then defined "image" to provide clearing to intended debate:

An Image is any physical, mental or spiritual representation or reflection of any person, place, thing or event.

Can we say or judge absolutely that an Image is an idol?

Definitely not...why?

An IDOL (eidolon in Greek) is primarily a phantom, a mirage in the mind, or an idea, fancy or value.

The notion IDOL is a conceptual value existing only in the mind. It is an exaggerated value attributed to any person, place, thing of event whether physical, mental or spiritual. Any real or imaginary thing need not constitute an IDOL.

The very THING or IMAGE itself is not necessarily an IDOL.

It is the judgment in the mind that makes a thing an IDOL...

DAX, who was in Fukukoa-ken, replied to the thread the next day:

Quote:

Originally Posted by LivingImage

An Image is any physical, mental or spiritual representation or reflection of any person, place, thing or event.

Quote:

Originally Posted by LivingImage

The very THING or IMAGE itself is not necessarily an IDOL.

Not all images are idols, but all idols are images. In other words, an idol is a subset of an image.

To use your definition above, and to go back to the thread title "Imahen ng mga Santo", is an "imahen" a mental representation? Or a spiritual one? Pareho hindi, because these exist physically. Hence, idols are physical-type images, therefore God says these should not be made for worship.

LIVING IMAGE was quick to respond to DAX:

Quote:

Originally Posted by Dax 
Not all images are idols, but all idols are images. In other words, an idol is a subset of an image.

Well, no problem with idols being an image...

Again:

To consider any being an idol is to give an exaggerated and excessive subjective value on the particular being making it a "realization" or "embodiment" of some ideal.

Hope you got the point.

Quote:

To use your definition above, and to go back to the thread title "Imahen ng mga Santo", is an "imahen" a mental representation? Or a spiritual one? Pareho hindi, because these exist physically. Hence, idols are physical-type images, therefore God says these should not be made for worship.

Can you give a sample of Spiritual image...let's see if you can defend your position that an image though physical can never be a spiritual image...

NAACHAN moderated the debate of LIVING IMAGE and DAX:

Quote:

Originally Posted by Dax

Therefore God says these should not be made for worship

Perhaps the question should be changed. Is the Catholic use of religious imagery invalid?

The exchange of ideas among the participants suggests their educational backgrounds, and this is exhibited clearly by argumentations that capitalized on proper quotations of the antecedent post. In replying, participants were critical in assessing what does/ do not conform to their belief and concept as far as religious visual piety is concerned. The transaction of definitions between LIVING IMAGE and DAX headed up that NAACHAN realized the need to moderate the debate by rephrasing of the question. GREENERY_YES found the thread very interesting and posted his curiosity of what could have been his life if he were not under the powers of conservative Catholic Church. He added that:

[I]t is Gods (sic) plan to save us. Napakasarap mabuhay na may kilala akong Diyos na totoo. Living in [j]apan proved me that [c]hristianity is our life. Hindi na maikakaila na sila man din ay nagiging Christiano na. Kung nagmamatigas ang puso pa ng marami, ito ay lalong ipaparamdam sa kanila ng Diyos hanggang sa matutunan nilang kilalanin ang Diyos.

(This is God's plan to save us. It feels great that I know a real God. Living in Japan proved me that Christianity is our life. It cannot be denied that even they (the Japanese) have become Christians. If one resists, God will show them the way to faith.)

The reply of GREENERY_YES strengthened the claim that Filipinos acknowledged the indelibility of Christianity in their culture. Within a host country that is agnostic, Filipinos, like GREENERY-YES, went online to engage in activities to post personal spirituality. While there were limitations on the environment, the participant assigned a signification to the representation of his religious belief. Like the impossibility of meeting all the members of the forum, and the limitation of the Internet to stream all images and voices that could suffice the need of reality and exceed the walls of hyper-reality, the participant acknowledged the presence of God. What is remarkable in the observation of GREENERY-YES is that while he raised the what-if of non-domination of Christianity in the Philippines, he realized that he and other Christians had been converting the Japanese. Here, offline religiosity is said to have inter-colonized cultures and spaces, and online religiosity provides an opportunity to validate this inter-religionality.

\section{Conclusion}

This paper provides insight into the relationship between religion and the Internet. In specific terms, it looked into the online Christianity of Filipino migrants in Japan. The discussions at Timog.com forum on religiosity and spirituality validate the widespread practice of online religion. Having been colonized by Spain which induced Christianity to their psyche, Filipinos realized that Catholicism is intrinsic to their daily lives - whether they are within the confines of the 
homeland or/and whether they are deployed to other countries to provide domestic and professional services. The online Filipino migrants are not self-confessed devotees of Christianity but they acknowledged the significance of their religion in their survival from displacement. The online environment, the website, facilitated their interaction as they engaged into traditional and debatable religious ideas and contexts.

The Filipino migrants of Japan used the Internet to engage in prayer, meditation, and rituals. The assigning of prayer requests as a sticky thread underlines the prayer and other spiritual mantras as a constant in daily lives of Filipinos offline and online faithful. But these Filipinos did not use the Internet to solely learn about or interact with other members of the forum and of their homeland, they were most interested in using the cyber space for expression of their personal and spiritual beliefs (as observed in this study by posting and soliciting of prayer requests, relaying of inspirational messages, bible sharing, and opening of debates that are results of philosophical musings). To a lesser extent, they were also interested in seeking differences and similarities within their sect, with other variants of their religion, and with other traditions.

Across the globe, Filipinos are identified as Christians. What is necessary to note, however, is that having been transported to an environment of immense difference in religiosity provided these Filipinos with an opportunity to rethink and reassess their affiliation and subscription to the variant of Christianity that they embody. Questions on the personal, communal and national effects of Catholicism in the Philippines have been aired out and have garnered postings that were expressive and individually-oriented toward Japanese experience of economic domination and sustainable development.

The personal conflict with one's religiosity is heightened by the debates on beliefs that range from visual piety, biblical interpretations, idolatry of totems and even service to God. Despite the differences in points of view and readings of the Bible, the participant are deemed to be committed to their spirituality and stood firm on the importance of such in their being absent from the homeland. The participants acknowledged that along with their financial remittances to the Philippines are their prayers of loved ones for their safety and security as the economy keeps them removed from the physical home and keeps them hooked to the online community.

There are several potential implications to the findings. While the Filipino online faithful may not find the Internet exchange of rethinking and comparing of their religious subscription and spirituality enough to free themselves from doubts and questions, they find contention in the fact that they are not alone in their calvary of reassessing their beliefs. The online faithful may be coming from different traditions of performing their religion but what experientially binds them other than being transmigrants is that they are woven by one thought - that there is God.

\section{References}

Brasher, B. (2001). Give me that online religion. California: Jossey-Bass, Inc.

Cacho, A. (2007). Symbolism in Religion: Ricoeurian Hermeneutics and Filipino Philosophy of Religion, Kritika 1(2), 122-131. [Online] Available: http://www.kritike.org/journal/issue_2/cacho_december2007.pdf (August 11, 2009).

Campbell, H. (2005). Spiritualising the Internet: Uncovering discourses and narratives of religious Internet usage. Online-Heidelberg Journal of Religions on the Internet, 1 (1). [Online] Available: http://archiv.ub.uni-heidelberg.de/volltextserver/volltexte/2005/5824/pdf/Campbell4a.pdf (February 17, 2007).

Cannell, F. (1999). Power and Intimacy in the Christian Philippines. Cambridge: Cambridge University Press.

CBCP Online. (2009). Manila Archidiocese launches 'Catextism'. [Online] Available: http://www.cbcponline.org/news/Archives/may2002/news6-may5.html (August 11, 2009).

Dawson, L \& Cowan, D. (Eds.) (2004). Religion online: Finding faith in the Internet. London: Routledge.

Ellwood-Clayton, B. (2003). The Lord is my textmate: Folk Catholicism in cyber Philippines. In Nyiri, K. (Ed). Mobile democracy: Essays on society, self and politics. Vienna: Passagen Verlag, 2003.

Helland, C. (2002). Surfing for salvation. Religion, 32(3), 293-302.

Helland, C. (2004). Popular religion and the Internet: A match made in [cyber]heaven. In L. Dawson \& D. Cowan (Eds.), Religion Online: Finding Faith on the Internet (pp. 23-36). New York: Routledge.

Helland, C. (2007). Diaspora on the electronic frontier: Developing virtual connections with sacred homelands. Journal of Computer-Mediated Communication, 12(3), article 10. [Online] Available: http://jcmc.indiana.edu/vol12/issue3/helland.html (June 23, 2009).

Hojsgaard, M. (2005). Religion and cyberspace. London: Routledge.

Hoover, S., Clark, Lynn \& Rainie, L. (2004). Faith online. Pew Internet \& American Project. [Online] Available: http://www.pewinternet.org (August 11, 2009). 
Ignacio, E. (2005). Building diaspora: Filipino community formation on the internet. New Jersey: Rutgers University Press.

Kong, L. (2001). Religion and technology: refiguring place, space, identity and community. Area, 33(4), 404-413.

Message of the Holy Father for the 36th World Communications Day. Internet: A New Forum for Proclaiming the Gospel. [Online] Available: http://www.vatican.va/holy_father/john_paul_ii/messages/communications/documents/hf_jpii_mes_20020122_worldco mmunications-day_en.html (August 11, 2009).

Nyland, R. \& Near, C. (2007). Jesus is my friend: Religiosity as a mediating factor in internet social networking use. Paper presented at the AEJMC Midwinter Conference, Feb. 23-24, 2007, Reno, Nevada.

Palumbu-Liu, D. (1999). Asia/American. Stanford, CA: Stanford University Press.

Paule, M. C. (2004). SMS capital of the world: A political economy of a wireless revolution in the Philippines. A masters thesis, Simon Fraser University.

Pertierra, R. \& Ugarte, E. (1994). Cultures and texts: Representations of Philippine society. Quezon City: University of the Philippines Press.

Pope John Paul II. (2002). Internet - A new forum for proclaiming the Gospel. [Online] Available: http://catholiceducation.org/articles/media/me0024.html (August 12, 2009).

Tigno, J. (2007). Serialized Filipino identity in Japan. Paper presented at The Osaka University Global Collaboration Center, July 27.

Timog Online Forum. (2009). [Online] Available: http://www.timog.com/.

Tordillo, M. (2007). Migration and religiosity: The Filipino seafarers onboard abroad. [Online] Available: http://www.stellamaris.net/silo/files/34.pdf (June 23, 2009).

Vatican Online. (2009). [Online] Available: http://www.vatican.va/.

Vertovic, S. (1999). Conceiving and researching transnationalism. Ethnic and racial studies, 22(2), 447-461.

Table 1. List of Activity Postings and Frequency (January 1 - June 30, 2009)

\begin{tabular}{|l|l|l|}
\hline Threads & Replies & Frequency \\
\hline $\begin{array}{l}\text { Prayer request (such as prayers addressed directly } \\
\text { to God) }\end{array}$ & 289 & $6.51 \%$ \\
\hline $\begin{array}{l}\text { Bible-related discussion (such as verse posts, } \\
\text { games, trivia, and sharing) }\end{array}$ & 1561 & $35.25 \%$ \\
\hline $\begin{array}{l}\text { Reflection (such as inspirational thoughts, } \\
\text { spiritual journeys, passion of Christ, testimonies } \\
\text { with God) }\end{array}$ & 678 & $15.31 \%$ \\
\hline $\begin{array}{l}\text { Gospel reference (such as daily Gospel posts, } \\
\text { Bible diaries) }\end{array}$ & 5 & $29.74 \%$ \\
\hline $\begin{array}{l}\text { Christianity debate (such as discussions on the } \\
\text { facts of the Bible, theories on the Creation, } \\
\text { debates on musings of theologians, philosophers } \\
\text { and social scientists, faith polls) }\end{array}$ & 1317 & $7.7 \%$ \\
\hline $\begin{array}{l}\text { Inspiration (such as collection of inspirational } \\
\text { stories, re-postings of parables and beatitudes) }\end{array}$ & 336 & $5.40 \%$ \\
\hline $\begin{array}{l}\text { Christian Entertainment devotion (such as } \\
\text { uploads and downloads of videos and music of } \\
\text { worship, Gospel song, etc.) }\end{array}$ & 240 & \\
\hline
\end{tabular}


Table 2. List of Activity Postings and Frequency (January 1 - June 30, 2009)

\begin{tabular}{|l|l|l|}
\hline Thread Title & Replies & Views \\
\hline A 40-day spiritual journey & 443 & 1,979 \\
\hline Bible Verse & 829 & 13,725 \\
\hline Bible Quiz Game & 154 & 3,103 \\
\hline Bible Sharing & 141 & 2,465 \\
\hline The Life and Mission of Jesus Christ & 111 & 3,144 \\
\hline Stories of Genesis & 135 & 3,400 \\
\hline $\begin{array}{l}\text { Why I choose not to associate myself with any } \\
\text { religion? }\end{array}$ & 146 & 4,499 \\
\hline $\begin{array}{l}\text { Imahen ng mga santo: Bawal nga ba? (Images } \\
\text { of saints: Forbidden?) }\end{array}$ & 239 & 6,420 \\
\hline Memory Verse Here & 147 & 4,431 \\
\hline $\begin{array}{l}\text { Tama po bang sambahin ang mga santo? (Is it } \\
\text { right to venerate the saints?) }\end{array}$ & 132 & 4,797 \\
\hline Christian Devotionals & 152 & 3,460 \\
\hline
\end{tabular}

